\title{
The Enhancement of Territorial Identities Through A Closer Synergy Between Companies and University to Developt Innovative Products as Symbols of a Cultural Identity
}

\author{
Elisabetta Benelli*, Jurji Filieri \\ Department of Architecture, University of Florence, Florence, Italy
}

Submission: March 10, 2018; Published: March 29, 2018

*Corresponding author: Elisabetta Benelli, Department of Architecture, University of Florence, Florence, Italy, Email: elisabetta.benelli@unifi.it

\begin{abstract}
An increasingly strong "net" of skills from different sectors orients innovative design processes even within fashion design and, at the same time, strengthen the local identities and protect cultural diversity, in order to transmit to future generations the tangible and intangible heritage tied to our traditions. The present study started with a mapping of Small \& Medium Enterprises (in fashion and design sectors) in Tuscany and then extended the research to the national context in order to strengthen the link between industry and academia. Actually there are a lot of products that contributed over the centuries to make Tuscany a symbol of tradition and the, so called, Made in Italy has became an intangible but of unquestionable importance value. The research therefore intends to create contact platform among the traditional knowledge, artisan competence and research activities conducted in universities in order to enhance the tradition of excellence and read them in a contemporary way.
\end{abstract}

Keywords: Fashion design; Territorial identity; Made in Italy; Innovation; Handcraft

\section{Introduction}

In Tuscany, more than in the rest of Italy, the textile sector and the clothing sector are considered "excellences". Thanks to this manufacturing base and these territorial characteristic, Tuscany is ideal for creating synergies able to rework the traditional know-how to new developments and applications made possible through the creation of more and stronger contacts with academic research community.

The research by promoting the creation of an industrial/ academic network has contributed to realizing a play of strategic development able to give value to the Tuscan product.

Today, more than it used to be in the past, it is important to have a wider view of the added value, given by the productions that involve different entrepreneurs in the same territory; an effective network that is able to grant a systematic, multidimensional and multidisciplinary innovation, as it creates synergies between different realities (industrial-craftmanship, innovation-tradition, etc.) [1].

We can assume that the small/medium companies need to comply with the market deep change: that is to stand out of the crowd and become an excellence, defend the quality of their own products by using technologies and being innovative, but mainly including in their business relations similar or complementary companies and create with them business networks or partnerships.

\section{From made in italy to made in...tuscany}

The expression Made in Italy contains all the Italian manufacturing production made of excellence, know-how and traditions bond to its territory and worldwide acknowledged. Industrial districts (IDs), a cluster of interconnected companies, mainly SMEs, operating in a small geographical area, are a phenomenon of Italy. Specifically, Italy has found in this organisational model a peculiar trait of its economy and a relevant source of socio-economic development and growth [2-4]. The industrial districts are characteristic elements of the Made in Italy production; they are homogeneous local productive systems characterised by a high concentration of micro/small and medium size companies with a high productive specialisation. This kind of organisation allows to divide the productive cycle into different phases; each phase is entrusted to independent companies which are part of the same geographical and productive net. This allows a high organisational flexibility and, at the same time, economies of scale that can make the finished product highly competitive, even in comparison with the product of bigger companies. 


\section{Territorial identity and local products}

The definition of «typical product» refers to a plurality of elements that do not only concern the characteristics of the product itself, but also a number of aspects relating to its production and to the territory of origin. A typical product is in fact closely linked to a territory, which should not be understood only as a physical place, but mostly as a set of conditions that contain numerous tangible and intangible assets, such as history, experiences and processing techniques [5-8]. The set of these values then represents the identity of the territory, of which these products are manifestation.

In Tuscany there are 15 districts identified by 2011 ISTAT census. One of the most important districts is Santa Croce sull'Arno situated between the provinces of Pisa and Florence: it can boast companies specialised in the whole leather production chain, from the tanning to the finished product, both in the shoes sector and in the leather industry. Other important districts are: the textile-district in Prato that is one of the biggest Italian industrial site and one of the most important worldwide centers in the field of yarns and woolen fabric [9]. The textile and clothing district in Empoli, the third in Tuscany as for its dimension and the Casentino and Val Tiberina textile and clothing district, situated in the province of Arezzo, which is famous for its Casentino cloth. The goldworking district, based in Arezzo, can boast a production that from the 70s up to now has ranged from modern and old style top jewellery to fine goldworking without stones, up to tableware sets and home decorations. The Capannori paper district, situated between the provinces of Lucca and Pistoia, holds $80 \%$ of the paper national production and about $40 \%$ of the national corrugated carton production [10]. The Poggibonsi wood and furniture district's strength is the production of kitchens, furniture and accessories and it can boast some successful top design companies [11]. Besides the furniture sector, there are enterprises ranging from caravanning to mechanical, getting to the famous marble mining and working district in Carrara.There are also a number of craft activities such as the processing of straw in Signa (the so called "gold of Signa») that at the end of the twenties inspired the film directed by René Clair: «A straw hat of Florence» or the laces of Tavarnelle that in the period before the second World War, when leather were beginning to be difficult to find, were used by Salvatore Ferragamo to create refined uppers.

\section{The importance of tradition}

The concept of typicality is strongly associated with that of tradition. The tradition, in fact, is the bearer of distinctive characters that show the uniqueness and authenticity of the product. Thus the traditional product takes on a connotation that could be called "mythological", thus allowing the past to merge with the present. So the memory of a bygone era becomes a fundamental added value in terms of uniqueness and symbolism, since it assumes a symbolic connotation and strongly representative of the place and of that culture [12-15].
In recent years, these issues have heightened the interest toward the typical products by consumers. In fact it is clear that these products perfectly meet the cultural trends of our time, both in terms of the protection and exploration, or learning practices and ancient knowledge. The contemporary user wants to rich out new experiences and authentic high educational content. Therefore strategies for commercial development of this type of product must, of course, take into account the relationship with artisanal production systems that characterizes them [16].

The limited production capacity, in a quantitative sense, is not able to fullfill the needs of a global market, but also makes them suitable for meeting the demands of small niche markets, focusing particularly on their needs.

\section{Identity as attractiveness}

In an increasingly globalized world, it is evident that the typical characteristics of a territory that represent the uniqueness and the identity can be not only a means of distinction from the masses, but also an important factor of economic growth through the creation of new products.

All tangible and intangible traits of local culture, due to the identity of the territory and populations that inhabit it, can be marked with the label of «typical» and possess the potential to become an attraction. The typicality, however, although necessary, is not enough to generate attractiveness: in fact, a resource «typical» to become profitable is to be organized and communicated in such a way as to be attractive. This means you must put in place a process that can make it understandable, visible and easily accessible [17].

An object, in fact, becomes attraction when it is recognized as such by the users, and the quality that determines the attractiveness goes beyond its «use value.»

The objective function of a product loses importance, while it becomes extremely significant to the value which is capable of transmitting [18]. In this way, a product differs from others on the market because of the high load of symbolic values it represents. In the contemporary market the affirmation of a product is thus not only due to its ability to arouse interest, but also and above all, to its symbolic value; therefore the cultural legitimacy is the real key of its success [19].

\section{Design and territorial identities}

In the process of exploitation of local and typical products identity, design, always covers plus a decisive role. In fact, in an increasingly critical economic scenario, where you need to find new tools for communication and enjoyment of the territorial cultural heritage, design is then able to create added value, to make available to users the cultural heritage without distorting or altering the essence and to generate innovative project proposals. In this view, the global economic crisis is a positive factor for the development and the rediscovery of the cultural riches present throughout the italian territory, providing the opportunity of a 
radical transformation which could lead to a new equilibrium, causing a major development at both economically and socially [20]. The territorial identity, expressed through culture, the tangible and intangible assets, becomes growth vector through design, which maintains access to knowledge. Design is able to create an innovative and necessary cultural development, without which we would run the risk of dramatically simplifying the content of territorial identity. What is essential, in fact, it is to keep firmly the relationship between project proposals and the complexity of the matter so, the designer's task is to provide a coherent response to the need to tell the identities through the projects [21-23].

The culture of the project - consistent, aware and responsible - is able to make the invisible visible, to bring out perceptions and intangible wealth, creating a connection between the past and future: it is essential to define what is the identity of a place,through a careful selection in the survey phase,to communicate it better [24].

\section{Conclusion}

The Italian product is very rich in intangible values and cultural meanings that have their roots in their own territory, in the social context and in the strengthened techniques. It stands out of the international landscape thanks to the quality of its forms, its care of details, but also the shapes and materials taken from its territory. The Italian product, characterised by a product-territory symbiosis, expresses its own human, social and historical values through a blend of intellectual and tangible knowing that eventually becomes know-how.

The present study (whose main objective has been to support the small-medium companies in their search for new synergies with universities to developt innovative products as symbols of a cultural identity) has enabled to pilot projects that will test the feasibility of this organisational model and the possibility of using it also in other contexts. The ethicality of this project is based on the realisation of products with a high added value, given by their uniqueness and by all those intangible aspects that connect it with a territory and its unique traditions.

The final goal of the research is the competitive growth of the traditional Tuscan products. The case study on which the research has developed is the Casentino's cloth.

Casentino was the first selected territorial model with the precise aim of serving as a guide, as a tool for orienting the formulation of strategies of action that may influence the quality of the territory. In fact, the project was developed with the ultimate goal of adding further value to the renowned and traditional «Casentino cloth», and to give renewed impetus to the companies that produce it: therefore it was necessary to be active on the factors that could contribute to strengthening their competitiveness and innovation on a globalised market by offering complex formal, technological and typological performance.

\section{References}

1. Argano L, Bollo A (2005) Gli Eventi Culturali. Ideazione, progettazione, marketing, comunicazione. Franco Angeli, Milano, Italy.

2. Ashby M, Johnson K (2010) Materiali e Design. CEA, Milano, Italy.

3. Becattini G (1998) Distretti industriali e made in Italy. Bollati Boringhieri, Torino, Italy, pp. 200.

4. Becattini G (2000) Il distretto industriale. Un nuovo modo di interpretare il cambiamento economico. Rosemberg \& Sellier, Torino, Italy.

5. Bodei R (1995) Le forme del bello. Bologna: Il Mulino, Italy, pp. 144.

6. Brock S (2014) Heritage. Artisan Publishers, Oklahoma, USA.

7. Butera F (2008) Innovazione e internazionalizzazione. Unindustria, Treviso, Italy.

8. Caselli G (2003) Casentino Guida storico ambientale. Le Balze, Grosseto, Italy.

9. Catania A (a cura di) (2011) Design, territorio e sostenibilità. Ricerca e innovazione per la valorizzazione delle risorse locali. Franco Angeli, Milano, Italy, pp. 112.

10. Della B, Pier L (1996) L'arte della lana in Casentino, storia dei Lanifici. Grafiche Calosci, Cortona, Italy, pp. 276.

11. Filippi F (2013) Il Panno del Casentino. Arti Grafiche Cianferoni, Arezzo, Italy.

12. Follesa S (2013) Design \& Identità. Progettare per i luoghi. Franco Angeli, Milano, Italy pp. 160.

13. Fortis M (1998) Il made in Italy. Il Mulino, Bologna, Italy.

14. Iabichino P, Gnasso S (2014) Existential Marketing. Hoepli Editore, Milano, Italy.

15. Mattia G (2013) Il neo-lusso. Marketing e consumi di qualità in tempi di crisi. Franco Angeli, Milano, Italy.

16. Morace F (2016) Consumautori. I nuovi nuclei generazionali. Egea, Milano, Italy.

17. Morace Francesco (2008) ll senso dell'Italia. Istruzioni per il terzo miracolo italiano. Libri Scheiwiller, Milano Italy, pp. 140.

18. Morace F, Santoro B (2014) Italian factor. Moltiplicare il valore di un Paese. Egea, Milano, Italy.

19. Niccolini F (1996) Bibbiena e il Casentino. Editrice Gemelli, Arezzo, Italy.

20. Norcini, Franca L (1996) Il vello d'oro: i vecchi mestieri e le antiche tradizioni del Casentino. Calosci, Cortona, Italy.

21. Norman DA (2004) Emotional design. Perché amiamo (o odiamo) gli oggetti della vita quotidiana. Apogeo Education, Milano, Italy.

22. Giovanni P (1993) Lo sviluppo della piccola e media impresa: vincoli e opportunità. Angeli, Milano, Italy.

23. Gustavo P (1926) L'arte della lana in Toscana. Firenze: Edizioni dell'Ente per le attività toscane.

24. Russo D (2016) Design \& Territorio. Università e aziende tra ricerca e innovazione. 40due Edizioni, Palermo, Italy, pp. 112. 
Your next submission with Juniper Publishers will reach you the below assets

- Quality Editorial service

- Swift Peer Review

- Reprints availability

- E-prints Service

- Manuscript Podcast for convenient understanding

- Global attainment for your research

- Manuscript accessibility in different formats ( Pdf, E-pub, Full Text, Audio)

- Unceasing customer service

Track the below URL for one-step submission https://juniperpublishers.com/online-submission.php 